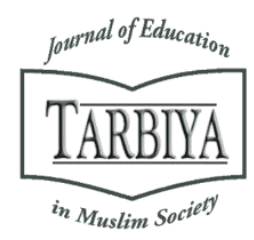

Available online at TARBIYA: Journal of Education in Muslim Society Website:

http://journal.uinjkt.ac.id/index.php/tarbiya

TARBIYA: Journal of Education in Muslim Society, 6(1), 2019, 88-102

\title{
THE PROSPECT OF INTEGRATED AND HOLISTIC MADRASAH EDUCATION SYSTEM (IHMES) IN THE PHILIPPINES: A Sustainable Approach to Prevent Violent Extremism
}

\author{
Jamel R. Cayamodin \\ Mindanao State University, Marawi City, Philippines \\ E-mail: jamelrcayamodin@gmail.com
}

Received: $28^{\text {th }}$ April 2019; Revised: $26^{\text {th }}$ May 2019; Accepted: $28^{\text {th }}$ June 2019

\begin{abstract}
The madrasah education system in the Philippines was recently impugned as a source of radicalized Muslim Filipino youths. This assertion was based on the presumption that most radicalized youths who happened to be members of either the revolutionary groups or the ISIS-inspired groups went through the diverse madrasah institutions in the country. This indictment, however, may be parti pris to the substantial majority of Muslim Filipino youths who served the nation in various capacities as also a product of various madrasah institutions in the Philippines and abroad. More vividly, many of the highly educated Muslim Filipino youths are actively engaged in various government and non-government programs on preventing and countering violent extremism. These two opposing views made the examination of the dynamics of the Philippine madrasah education system imperative to vindicate the issue. Using analysis of documents, the study found that there are challenges and gaps in the implementation of the madrasah programs even though it is mandated by existing legislations, policies, and peace agreements. Thus, a sustainable integrated and holistic madrasah education system (IHMES) acquiescent to the religio-cultural orientations of Muslim Filipinos is proposed to empower Muslim communities, eliminate various social ills particularly violent extremism, and meaningfully participate in nation-building.
\end{abstract}

Keywords: IHMES; Muslim Filipinos; Bangsamoro; Philippine Madrasah System; Integrated and Holistic Education

\begin{abstract}
Abstrak
Sistem pendidikan madrasah di Filipina akhir-akhir ini dibantah telah menjadi sumber bagi radikalisasi pemuda Muslim Filipina. Pernyataan ini didasari pada dugaan bahwa generasi muda yang paling banyak terpapar radikalisme dan menjadi anggota grup revolusioner ataupun grup yang terinspirasi oleh ISIS menempuh pendidikan di berbagai institusi madrasah di negara tersebut. Meski begitu, dakwaan ini mungkin saja merupakan prasangka atas adanya mayoritas pemuda Muslim Filipina yang bekerja dalam melayani negara di bergagay bidang yang juga merupakan lulusan dari institusi-institusi madrasah, baik di dalam maupun luar Filipina. Lebih jelasnya lagi, kebanyakan pemuda Muslim Filipina yang berpendidikan tinggi berperan aftif dalam berbagai program, baik yang diadakan oleh pemerintah maupun swasta dalam rangka menangkal dan melawan ekstrimisme dan kekerasan. Kedua pandangan yang menentang ini membuat pemeriksaan dinamika sistem pendidikan madrasah Filipina sangatlah penting, demi membuktikan kebenaran kasus ini. Dengan menggunakan analisis terhadap dokumen yang ada, studi ini pun menemukan fakta bahwa terdapat tantangan dan kesenjangan dalam penerapan program madrasah, meskipun mereka telah berada di bawah pengawasan perundang-undangan yang ada, kebijakan, dan juga perjanjian kedamaian. Oleh karenanya, sebuah sistem pendidikan madrasah yang terintegrasi dan holistik yang berkelanjutan (integrated dan holistic madrasah education system, IHMES) sepakat pada orientasi agama-budaya Muslim Filipina agar dapat diajukan, hal tersebut betujuan dilakukannya pemberdayaaan komunitas Muslim demi menyingkirkan berbagai penyakit sosial, terutama ekstrimisme kekerasan, dan yang juga berarti sebuah partisipasi dalam membangun negara.

Kata kunci: IHMES, Muslim Filipina; Bangsamoro; Sistem Madrasah Filipina; Pendidikan Terintegrasi dan Holistik
\end{abstract}

How to Cite : Cayamodin, J.R. (2019). The Prospect of Integrated and Holistic Madrasah Education System (IHMES) in the Philippines: A Sustainable Approach to Prevent Violent Extremism. TARBIYA: Journal of Education in Muslim Society, 6(1), 88-102. doi:10.15408/tjems.v6i1. 11628.

Permalink/DOI: http://dx.doi.org/10.15408/tjems.v6i1. 11628 


\section{Introduction}

The madrasah (pl., madaris) education institutions in the Philippines had been existing as early as the 15 th century, prior to the coming of foreign colonizers (Abubakar, 1983). By the time alien invaders met the resilient Muslims in 1521, there were already existing informal religious schools or madrasah that propagated the basics of Islam among the people in the communities (Madale, 1981: 261). Madrasah had become an established institution responsible for the deepening of the Islamic process in the southern Philippines (Boransing, Magdalena and Lacar, 1987). Although the development of madrasah education in the contemporary Muslim Filipino society has been a consistent integral component of notable national legislations (i.e., Republic Act (RA) No. 6734 as amended by RA No. 9054 and RA No. 11054; RA No. 9997; and RA No. 10908) and is embodied in past peace agreements (i.e., the 1976 Tripoli Agreement; the 1996 Final Peace Agreement; and the 2014 Comprehensive Agreement on the Bangsamoro) which were signed between the Philippine government and Muslim revolutionary groups such as the Moro National Liberation Front (MNLF) and Moro Islamic Liberation Front (MILF), madrasah education has never been fully developed as it was envisioned in these legislations and peace agreements due to very confined efforts and the absence of a central authority in the Department of Education (DepEd) for all types of madrasah institutions.

Until the early 21st century, the Department of Education (DepEd), the Commission on Higher Education (CHED), and the National Commission on Muslim Filipinos (NCMF) were seen to have flaws in the full and effective integration of the country's madrasah institutions across levels into the national education system even though these had existed in past centuries as integral part of Muslim Filipino society. Offices authorized to manage Madrasah programs nationwide were underperformed and had appeared to be unstable due to lack of legal and regulatory frameworks. It must be noted that the proliferation of unaccounted Madrasah institutions is partly caused by the absence of legal and regulatory framework that often resulted to constant transfer of authority in managing the madrasah programs. This was manifested in the abolishment of the Office of the Undersecretary for Muslim Affairs in the DepEd in 2010. The departure of Manaros B. Boransing from DepEd as Undersecretary for Muslim Affairs marked the cease of higher and central authority for Madrasah in the country. Accordingly, this has resulted to the passive relationship between the implementers of Madrasah education programs vis-à-vis Muslim communities due to various issues including religio-cultural differences. This is evident especially when most if not all of the higher ranking officials who implement the programs in DepEd are non-Muslims who largely focus on administrative or procedural aspect rather than the substance or learning content of the Madrasah education.

Consequently, since the arrival of Muslim Filipino students who studied from foreign universities, particularly in the Middle East and in North African countries, this scenario made many Muslim groups and individuals independently established their own madrasah institutions (Cayamodin, 2019). More often, these madaris are largely influenced by the founders' religio-cultural preference inherited from foreign Islamic countries without being sanctioned by authorities. This mushrooming establishment of independent madaris is further fortified by the absence of inclusive legal and 
regulatory frameworks. Hence, the four types of madrasah institutions, as discussed in this paper, had emerged in the passage of time. Accordingly, due to lack of government supervision, financial support and efficient inclusive approach to develop these institutions, they have become subject of both external and internal forces to promote alien agenda that might be a threat to national security and wellbeing of the Muslim society. The prevailing question on the role of madrasah institutions in the Muslim community vis-à-vis violent extremism led the researcher to examine the dynamics of these institutions. Thus, the study is designed to answer the following questions: (1) what are the types of Madrasah institutions in the Philippines? (2) how can these institutions operate under an integrated and holistic education system (IHES) attuned to the religio-cultural orientations of Muslim Filipinos? and (3) how will IHES work legally and administratively in the Philippines as a Christian-dominated country. These research questions are the main thrust of this study.

\section{Method}

The study is qualitative and exploratory in nature which adopts analysis of documents as a primary method. The researcher tried to examine legal documents issued or signed by the Philippine government authorities vis-à-vis Muslim revolutionary groups. These include Executive Orders, Republic Acts, DepEd Orders, Peace Agreements, proposed Bills in the Philippine Senate and House of Representatives, Websites, and Power Point presentation of education expert. The researcher believes, to a major extent, that this method is appropriate in order to effectually analyze the plight of Madrasah institutions in the Philippines, and devise a suitable Madrasah education system for Muslim Filipinos.

\section{Results and Discussion}

Types of Madrasah Institutions in the Philippines

Currently, there are four types of madrasah institutions that are simultaneously operating in the Philippines. Except for madrasah in public schools implementing Arabic Language and Islamic Values Education (ALIVE) programs, all of these madrasah institutions are managed by private organizations and/or individuals. The following are the basic characteristics of these diverse Madrasah institutions:

1) Traditional Arabic Madrasah: This refers to the mainstream type of madrasah that had existed as early as 15 th century (Abubakar, 1983). It is considered the oldest type of madrasah that adopted the Arabic language as medium of instruction. Its operation is held during weekends and weekdays, depending on students' preferences vis-à-vis their conventional education (as most students going to this type of madrasah have concurrent schooling). It also has formal curriculum called manhaj frequently adopted from the Arabic Universities in the Middle East such as, among others, Saudi Arabia, Jordan, Qatar, Syria and Kuwait, as well as North African countries including Egypt, Algeria and Sudan. Although these curricula are not recognized under the Philippine education system, they are recognized in foreign universities of the abovementioned countries subject to the existing rules and regulations of those countries. Students are also graded based on Arabic standards from Primary (Ebtidaiyyah) to Tertiary (Kulliyyah), while teachers (Asatidz) need to be highly qualified and learned persons (Ulama) and should preferably possess diploma obtained from an Arabic University because of the nature of teaching resources 
used that are normally written in Arabic. A large number of madrasah institutions in the country are believed to be categorized under this type. These institutions do not receive support from the government; rather they are sustained by the Muslim communities through the collection of sadaqa (optional alms), zakat (obligatory charity), awqaf (endowments), and donations from foreign institutions. Beginning in the 1950s, formal traditional Arabic madrasah were instituted in Muslim provinces in Mindanao (Marohomsalic, 1995).

2) Madrasah Toril: This type of madrasah is not included among the categories of madaris as defined by the DepEd because its methods and approaches are relatively different from the rest of the Philippine education system. It requires students to stay inside the school campus premises as identified and designated by the school administrator or owner. This is considered non-formal education due to its nature and approach of not following a certain standard curriculum recognized under the DepEd or CHED. More often than not, this Madrasah does not impose age requirement, and offers free tuition, lodging, food, and allowances for students subject to the available financial resources coming from the people in the community (Madale, 1981) and/or foreign donors beginning in the late $20^{\text {th }}$ century. Concurrent to the work of Boransing, Magdalena and Lacar (1987), this type of Madrasah was part of the earliest educational institutions to have been established in the Muslim communities which was regarded in the past as Qur'anic school because of the coverage of teaching and learning contents for the students concentrated on the study of Qur'an and Sunnah as primary sources of Islamic thought.
Similar to the practice in other Southeast Asian countries, this type of Madrasah is also called pondok, pesantren, or boarding school in countries such as Malaysia, Indonesia, and Thailand (Lukens-Bull, 2010). Learning of students in this madrasah type focuses on memorizing and understanding the Qur'an, the sunnah (tradition) of the Prophet Muhammad (S.A.W.), as well as other religious courses such as Islamic law (Shari'a) and jurisprudence (fiqh). It is considered monotonous as students under this Madrasah are trained or taught by only one or very few learned persons in a routinely manner for two to three years (Hadji Latif, 2014). Among the earliest progressive and well-established madrasah toril in the country includes Zaid Bin Thabit Qur'anic Institute in Mindanao State University (MSU) - main campus, Marawi City founded in 1993; Ubay Bin Kaab Qur'anic Institute in Cotabato City founded in 1998; and Almaarif Educational Center, Inc. in Baguio City established in 1995. These Madrasah institutions have, to some extent, contributed to molding and providing quality human resources such as Ulama (scholars), Du'at (missionaries) and professionals who are active in the reformation of Muslim communities. However, the contribution of this type of madrasah to Muslim communities is largely seen on the spiritual aspect. Except for those who have prior conventional education before undergoing madrasah toril or those who furthered their education in the conventional learning institutions, most graduates of madrasah toril are onedimensional which is believed to be in contradictory to the projected human resource that will be produced under the concept of holistic education system envisioned in this study. 
3) Integrated Madrasah: The integrated madrasah is part of the recent development of madrasah institutions in the Philippines, which is believed to be a result of Islamicization of Human Knowledge (IOHK) movement that began after the 1977 First World Conference on Muslim Education in the Holy City of Makkah (Saqeb, 2000), and advanced by contemporary Muslim scholars (such as Syed Muhammad Naquib al-Attas, Isma'il Raji al-Faruqi, Abdul Hamid AbuSulayman, and Muhammad Kamal Hassan) (Ali 2017). This type of madrasah is considered the closest to the Integrated and Holistic Education System (IHES), which will be discussed in the next section. Curo (2015) found that this type of madrasah is the most progressive and has a strong potential to help transform Muslim communities in the Philippines. These madaris are referred to by the DepEd as 'private madaris' in DepEd Order No. 51, s. 2004 (as amended by DepEd Order No. 40, s. 2011) and implement the Refined Elementary Madrasah Curriculum (REMC). Among the most progressive integrated Madrasah in the country include Asia Academic Integrated School, Inc. founded in 2012 in Pasig City; Ibn Siena Integrated School Foundation founded in 1994 and Philippine Integrated School Foundation founded in 2000 - both are located in Marawi City.

4) Madrasah in Public Schools: This institution could have been the tangible fulfillment of various legislations and peace accords signed between the Muslim revolutionary groups and Philippine government beginning in the 1970s. DepEd public schools administer Arabic Language and Islamic Values Education (ALIVE) program. This madrasah program is fully funded and implemented by the national and local governments by virtue of DepEd Order No. 51, s. 2004 (as amended by DepEd Order No. 40, s. 2011). Over the years, from its inception in 2004 up to this date, ALIVE program has evolved and widened its coverage with the laudable support of the local government units (LGUs) especially in provinces and cities outside Bangsamoro Autonomous Region in Muslim Mindanao (BARMM) including Metro Manila where Muslims are considered significant minority. However, the implementation of this DepEd sponsored type of Madrasah faced criticisms from different Muslim stakeholders including ALIVE teachers (Asatidz), parents, Ulama (Muslim scholars), community leaders, and academicians when it appeared to undermine the existence of other types of madrasah. The criticism is further heightened due to various administrative flaws and the constant demotion rather than promotion of the program particularly on administrative aspect. Since 2010, there was a seemingly constant top-bottom transfer of authority under DepEd Central Office in managing ALIVE programs, which suggests the lack of a clear and established legal and regulatory framework for its implementation. Currently, ALIVE programs are administered by multiple bureaus and offices within the DepEd. The sustainability of ALIVE programs is uncertain as believed by many because its implementation is neither by virtue of a Republic Act emanated from the Philippine Congress nor by power of an Executive Order issued by a Philippine president, rather it has been implemented by virtue of DepEd Orders. In addition, the implementation of the ALIVE program is generally noncompulsory to Muslim children especially in provinces and cities outside BARMM. Muslim students 
may or may not undergo with the program, but they are still able to complete elementary and secondary education levels and allowed to proceed to higher education in colleges and universities.

The unprecedented ineffective concurrent existence of the above diverse madrasah institutions is a manifestation of the lack of unifying legal and regulatory framework adopted in the country. This scenario is even more disheartening when large number of the madrasah institutions in the country especially in the case of traditional Arabic madrasah and madrasah toril do not receive support from the government since their inceptions. This disconcerting nature of the madrasah institutions in the Philippines instilled imbalanced education among Muslim youths that brought longstanding negative effects to the social wellbeing of Muslim Filipinos in the country. Moreover, the path to take advantage of the vulnerability of Muslim youths becomes wide open when graduates from the madrasah institutions are not given due recognition and accommodation in the Philippine bureaucracy. This made the study argue that traditional Arabic madrasah and madrasah toril are vulnerable from the threat of unnoticed infiltration of radical ideology due to various challenges faced by the students and administrators. These include lack of employability of graduates, poor facilities, unstandardized curricula and learning resources, parochial pedagogy, lack of infrastructural development, and unstable salaries for teachers (asatidz). This scenario is partly caused by the negligence of certain government agencies for not recognizing the potential role of these institutions to develop the Muslim communities and contribute in nation-building.
The Integrated and Holistic Education System (IHES)

The Integrated and Holistic Education System (IHES) was first introduced in the early 1990s by Engineer Hasni Mohammed, education content expert in the Organization of Islamic Cooperation and Chief Executive Officer of the Adni Islamic School (AIS) in Kuala Lumpur, Malaysia. The AIS is a private school registered with Malaysia's Ministry of Education that was set up in 1994 and is considered as an experimental venue for the IHES. The AIS is designed to promote a holistic, quality and balanced education integrated with moral values suitable to all peoples irrespective of religious, cultural, or racial backgrounds. Thus, the school program is directed towards inspiring the students to realize their spiritual, intellectual, emotional, and physical potentials, given their various inherent and acquired abilities (Sekolah Islam Adni n.d.a).

The school's philosophy states that "education is aimed at a balanced growth of personality through tarbiyyah of the spirit, the intellect, the emotions and the physical willingly and joyfully for the sake of Allah (SWT)" (Sekolah Islam Adni n.d.b). Its primary mission is to "develop excellent, holistic individuals towards building an excellent generation based on total submission to Allah (SWT)" and its objectives are "(1) to provide an integrated educational program suitable for the early development of the child from pre-school to secondary level that produces a wholly practicing Muslim; (2) to provide a broad spectrum of avenues and opportunities for maximum potential growth to help individuals achieve excellence in all aspects; and (3) to develop the human potential and impart the necessary knowledge in order to build an excellent ummah (community)" (Ibid.). 
The school's learning content encompasses (1) hafazan (memorization) and qiraati (reading) of the Qur'an and sunnah ; (2) language development (in Arabic, Malay, English, and Mandarin); (3) mathematics and science; (4) basic arithmetic; (5) information and communications technology (ICT); (6) arts and crafts; (7) daily do'as (supplication); and (8) Islamic Studies [e.g., akhlaq (ethics), seerah (biography of the Prophet Muhammad), fiqh (Islamic jurisprudence), and tauhid (doctrine of the unity of God)] and its multilevel curriculum includes (1) core curriculum; (2) co-curriculum; (3) extra-curriculum; (4) national curriculum; and (5) international curriculum (Ibid.).

In sum, the IHES — as seen in AIS_focuses on outcome-based learning which aims on the immersion of knowledge, character building (akhlaq), academic achievement, and application in life (Muhammed, 2012). It indicates that the system encompasses all aspects of human life with its various potentials to develop in different levels. It therefore suggests that all types of madrasah institutions existing in the Philippines may be integrated under IHES. The main question at this juncture is how can IHES be contextualized in the Philippines given the diversity of madrasah institutions in the country. The following section discusses the possible configuration of IHES in the Philippine education system which requires an inclusive legal and regulatory framework.

\section{From IHES to IHMES: The Philippine Context}

There are two approaches in which the IHES can be implemented in the Philippines: through administrative as well as in curricular and content aspects. For contextualization, we now call the IHES as the IHMES or the Integrated and Holistic Madrasah Education System. These approaches are proposed due to the diversity of madrasah institutions, as discussed above, and the lack of established legal and regulatory framework governing these institutions.

\section{First Approach: Administration}

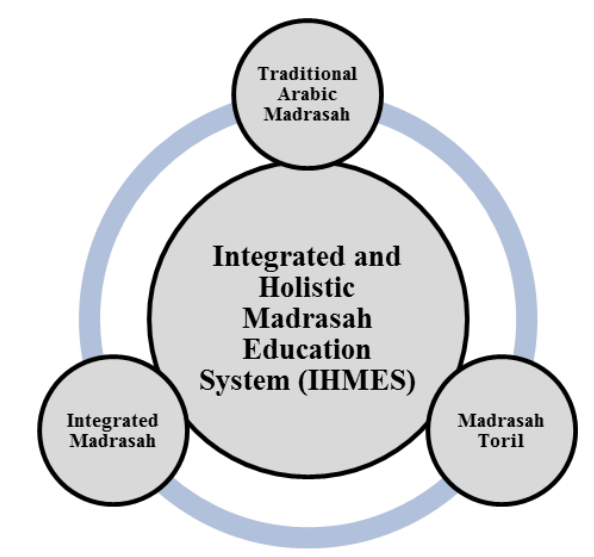

Figure 1. The Integration and Administration of Madaris in the Philippines under the Integrated and Holistic Madrasah Education System (IHMES)

Figure 1 indicates the regulation of all types of private madrasah institutions in the country in order to provide a competitive and holistic education to Muslim children according to their historical and cultural identities as mandated by RA No. 10908, RA No. 11054, and RA No. 9997. For an effective administration of the IHMES, a standard regulatory framework should be crafted by various madrasah stakeholders and concerned government agencies. This framework should then be implemented proportionately across all types of madrasah, except for ALIVE in public schools because they are governed by DepEd Orders. The above figure also indicates that all the three types of madrasah institutions will follow a single education standard, making their curricula, learning contents, and pedagogies exist synchronously under the IHMES. With regards to the existing practice in the madrasah toril requiring students to be confined in the premises of the madrasah, this practice will continue only for those students who opted to stay in the boarding house or dormitory as may 
be provided by the school. This will give ample time for students under madrasah toril whose primary concern is to memorize the Holy Qur'an and Sunnah, and study courses on Islamic jurisprudence, Islamic law, and ethics (adab) during evening or night time, without jeopardizing their rights to learn conventional courses on languages (e.g. Arabic, English, Bahasa Malay or Indonesia and Filipino), mathematics, sciences and others during the day. Analogous to the studies of Kimpa (1991) and Arsad (2007), this framework will allow the full and broader integration of various types of madrasah education in the Philippine education system, and uplift the status of madrasah teachers (asatidz) in the Philippine bureaucracy. This study assumes that combining these three types of Madrasah under IHMES parallel with financial assistance and administrative support from certain government agencies will make it easier for the authorities to identify the strengths and weaknesses of the institution. This will effectively address the problem on the current fragmentized Madrasah institutions in the country that are believed to be vulnerable on the threat of radical ideologies.

\section{Second Approach: Curriculum and Learning Content}

Although madrasah schools, as espoused by Majul (1986), have a common core curriculum, there is a need to integrate curricula and learning contents from all types of madrasah, which will eventually make Muslim children as what AlAttas (1980) referred to as 'good man' (insan adabi) and reach the state of being a 'full human' (insan kamil) as viewed by Fethullah Gulen (Carrol, 2007) as a result of a holistic education. Figure 2 shows the proposed curricular and learning content design under the IHMES. In this case, the learning contents under the traditional Arabic madrasah and the madrasah toril are being integrated with the existing curriculum of the integrated madrasah that are accredited by the DepEd. Values and peace education are emphasized to prevent or counter violent extremism at the very early stage of madrasah education.

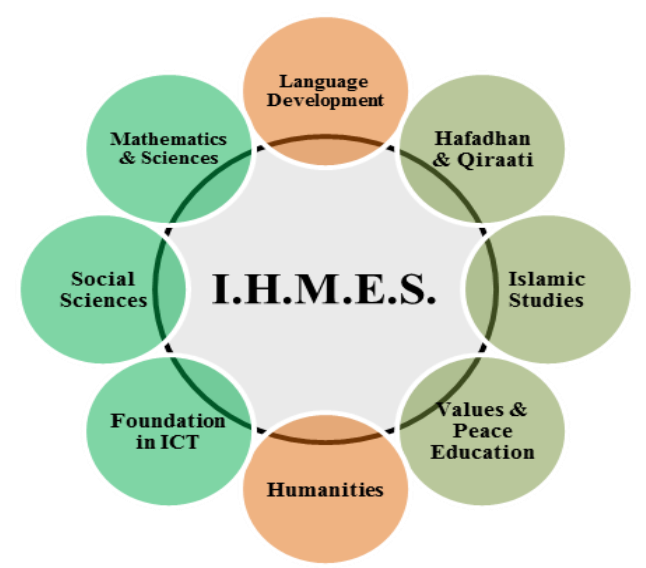

Figure 2.Curricular and Learning Content Integration under the Integrated and Holistic Madrasah Education System (IHMES)

Figure 2 further indicates the nature of IHMES as multidisciplinary concurrent to the curriculum of basic education and ALIVE program prescribed by the DepEd. It shows the integration of subjects taught in the traditional Arabic madrasah and madrasah toril with the mainstream subjects taught in the integrated madrasah and in public schools under DepEd. Analogous to the IHES adopted in AIS, as discussed above, the main argument of this study is that the integration of the major or common traditional Arabic madrasah and madrasah toril subjects [i.e., hafadhan (memorization) and qiraati (reading) of the Qur'an and Sunnah as well as Islamic Studies subjects particularly Islamic ethics (akhlaq)] into the curriculum used in the mainstream private and public schools accredited by DepEd is a significant aspect for an effective implementation of IHMES. The teachings of values and peace education as mandated by Executive Order No. 570; languages such as English, Arabic and Bahasa Melayu or Bahasa Indonesia; Islamic Studies including Halal lifestyles with basic components of Halal industry as mandated by RA No. 
10817, and Islamic economics or Islamic Financial System (IFS) as contained in Senate Bill No. 2231, House Bill No. 8281 and RA No. 6848 which are all religiously and culturally amenable to Muslim Filipinos, are imperative in the design of curriculum and substantiate learning content under IHMES.

The above proposed approach is not only confined to making the Madrasah education holistic and integrated attuned to the religiocultural orientations of Muslim youths, but it will also protect and guarantee the continuous and effective existence of all types of Madrasah institutions in the Muslim communities in which existence is the primary concern or fear of Muslims in order not to be alienated from their religion (Tamano, 1981: 310). In fact, the nationwide adoption of IHMES can be perceived as empowerment of the said institutions as partner of the Philippine government in nation-building. Madrasah institutions will then play a vital role in addressing various problems in the Muslim communities particularly the major triumvirate quandaries such as (1) ineffective education system, (2) underdeveloped economy, and (3) internal schism.

Concurrent to the philosophy of IHES, the adoption of IHMES is expected to prepare Muslim youths with a balanced growth of personality through tarbiyyah of the spirit, the intellect, the emotions and the somatic aspect of their lives. IHMES, given its components as shown in Figure 2, is presumed to be attuned to the religio-cultural orientation and sensitivities of Muslim Filipinos. In the long run, Muslim communities are believed to be transformed into what the Qur'an described as "ummatan wasata" or balance community that recognizes both profane and mundane or harmonizes the relationships between faith and logic which are all important for the existence of human beings in this world. IHMES is designed to reduce both cultural and religious extremism that had caused the backwardness of the Muslim Filipino society in the country. It will warrant a paradigm shift in the way Muslims look at their relationship with the non-Muslim dominant population and the Philippine government.

\section{Legal and Administrative Requirements for the Implementation of IHMES}

To implement the IHMES in the Philippines requires legislative and executive initiatives in order to provide clear inclusive legal and regulatory framework governing madrasah institutions. This should be implemented throughout the country by an interagency body as authorized by the Philippine government. Figure 3 shows the legal and administrative recommendations for the implementation of the IHMES.

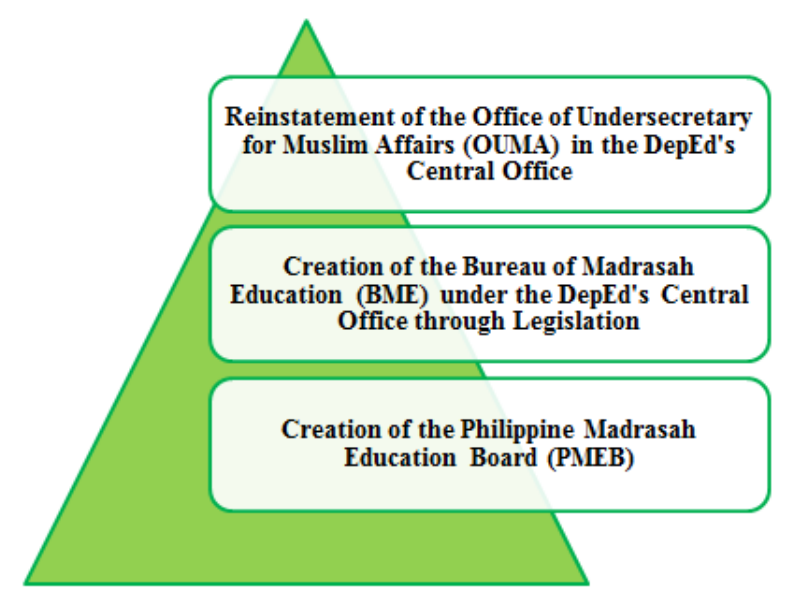

Figure 3. Legal and Administrative Requirements for the Implementation of IHMES in the Philippines

Reinstatement of the Office of Undersecretary for Muslim Affairs in the Department of Education's Central Office:

It must be remembered that one of the highlights of Pres. Duterte's platforms during his campaign in 2016 is to correct the historical injustice done to Muslim Filipinos. This study argues that the abolition of the DepEd Office of Undersecretary for Muslim 
Affairs in 2010 was a form of injustice done to Muslims when the said office was silently abolished by the higher decision making authority in DepEd without consultation with the people who are directly affected particularly the Madrasah teachers (Asatidz). Nevertheless, the reinstatement of the said office will pave the way for further development of the previous madrasah programs that have been stalled due to lack of a central authority in managing the programs. It will then signal the fulfillment of the current administration's promise to correct the historical injustice done to Muslim Filipinos. The said office, for purposes of accommodation, can now be renamed as Office of Undersecretary for Madrasah Education (OUME).

In case of administrative or legal difficulties to accommodate the same, the institution of the Office of Assistant Secretary for Madrasah Education (OASME) though it is not at par with the former will be sufficed in order to carry out various Madrasah or Muslim Education related programs in the whole country. The reinstatement of the OUME or institution of OASME carries a lot of positive implications to the Philippine government vis-à-vis international communities especially from the Organization of Islamic Cooperation (OIC) member countries. This will eventually lead to the different levels of partnership and cooperation in the promotion of quality education between the Philippines and OIC member countries. At this juncture, IHMES can be fully and effectively implemented with sufficient financial and administrative support coming from both Philippine government and OIC member countries as experienced in the past during the time of DepEd Undersecretary Manaros B. Boransing. This, at a major extent, will address the ineffective education system existing for decades in the Muslim communities.

\section{Creation of the Bureau of Madrasah Education (BME) under the DepEd's Central Office through Legislation:}

The passage of a clear inclusive legal and regulatory framework that will lead to the creation of a dedicated bureau on Madrasah programs within the DepEd has enormous significance for the development of integrated and holistic madrasah education system in the country. In fact, this is a major component of House Bill No. 6644 (or the Madrasah Integration Act of 2017). The bureau-as provided in Section 3 of the bill-will have divisions on (a) curriculum and instruction, (b) human resource management and development, (c) finance and scholarship, and (d) infrastructures and projects. In fact, the said Bill should have contained two other divisions on research and external relations. The former will provide scientific approach to monitor the progress and effective implementation of IHMES, while the latter will promote linkages and cooperation between OUME/OASME or BME and the Madrasah education institutions in foreign Muslim countries especially in Southeast Asia such as Malaysia, Indonesia and Brunei that have proximal religio-cultural orientations with the Muslims in the Philippines. The bureau will be tasked to supervise and manage the development and implementation of IHMES and other Muslim basic education related programs for Muslim Filipinos.

This study argues that since there is already a House Bill filed before the $17^{\text {th }}$ Congress by Hon. Salvador B. Belaro Jr. in November 2017 [i.e. House Bill No. 6644 "An Act Creating the Bureau of Madrasah Education (BME) in the Department of Education (DepEd) to strengthen the Madrasah Education Program and 
Appropriating Funds Therefor"], there is a need to enhance and re-file the same Bill before the $18^{\text {th }}$ Congress as it did not progress during the $17^{\text {th }}$ Congress due to lack of appreciation of the legislative branch of the government. However, since the proponent of the Bill (i.e., 1-Ang Edukasyon Party List) did not win a seat for the $18^{\text {th }}$ Congress in the recent May 2019 elections, the support of other Party Lists that are advocates of education or the Muslim legislators for sponsorship and re-filing of the Bill in the Philippine Congress is imperative.

In addition, there is also a need to come up with the Senate version of the House Bill No. 6644 in the upper house of the Congress and have it certified by the Philippine President as urgent Bill in order to finally alleviate the administration of Madrasah institutions and eventually address various social issues in the Muslim communities through the adoption of IHMES nationwide. The law on Madrasah education like that of House Bill No. 6644 must be passed in order to get rid of mere DepEd Orders which are highly subjective and dependent on bureaucratic, administrative, and political dynamics in the DepEd and Malacanang Palace as witnessed in the previous administrations. The establishment of the envisioned BME will usher the nationwide promotion of IHMES and guarantee the sustainability and effective implementation of the system in order to effectively prevent violent extremism in the Muslim communities.

\section{Creation of the Philippine Madrasah Education Board (PMEB):}

As in the case of "Philippine Halal Export Development and Promotion Board" espoused in RA No. 10817, the Creation of "Philippine Madrasah Education Board (PMEB)" is equally imperative. The Board will be composed of five agencies of the government, namely the Department of Education (DepEd), the Commission on Higher Education (CHED), the National Commission on Muslim Filipinos (NCMF), Department of the Interior and Local Government (DILG), and the Technical Education and Skills Development Authority (TESDA). The Board will then collaborate with the other madrasah stakeholders including the ulama, asatidz, community leaders, and professionals in the administration and development of madrasah institutions in the country.

The five government agencies constituting the proposed Philippine Madrasah Education Board will manage the promotion of the desired integrated and holistic type of education for the Muslim communities. First, the DepEd being an agency responsible for basic education in the whole country will be the lead agency to advance IHMES. The reinstatement of OUME or institutions of OASME and creation of BME will work perfectly to develop and advance Madrasah programs and institutions. The former will participate in the decision-making process in DepEd, while the latter is in the implementation of policies, standards, and guidelines. Second, NCMF which mandates, by virtue of RA No. 9997, include the development of Madrasah programs specifically under Article II, Section 8, Paragraph $U$ to $\mathrm{Y}$ and Section 11, Paragraph B, the role of the Bureau of Muslim Cultural Affairs (BMCA) with its "Division of Madrasah Development" can be maximized in partnerships with the other agencies. NCMF can be the lead government agency in pacifying the Muslim communities on the proposed nationwide integration of Madrasah institutions and adoption of IHMES. Third, the participation of CHED is 
very important being the agency responsible for Higher Education Institutions (HEIs). CHED should take care of the Madrasah institutions that have tertiary or college (kulliyyah) levels. Fourth, the DILG has, no doubt, a very significant role in any implementation of Madrasah programs to the grassroots level. The mandate of the Office of Undersecretary for Muslim Affairs and Special Concerns under DILG can be maximized to promote IHMES. The possible role of the said office is to make sure that Local Government Units (LGUs) such as Municipalities, Cities and Provinces all over the country support the Madrasah programs administratively and financially as in the case of Madrasah programs currently operational in the cities of Metro Manila. And lastly, TESDA, as an agency designed to provide jobs for the nation, will be responsible for integrating skills and competencies to Muslim students especially when they reached K-12 levels. The participation of TESDA to the Madrasah Education Board will facilitate the employability of students coming from IHMES. Consequently, the creation of PMEB with the nationwide implementation of IHMES will address the issue on the lack of employment and endemic poverty which are believed to be parts of the root causes of the emergence of violent extremism (Maute, 2018; \& Curo, 2019).

In addition, this study would like to put forward that the five government agencies should all establish their focal offices or bureaus dedicated for Madrasah education. This will ensure the effective, standard and sustainable implementation of various Madrasah programs nationwide. Apparently, the participation of the BARMM government in the PMEB as, to some extent, mandated by RA No. 11054 is another supplemental exertion to pave the way for the inclusive implementation of the IHMES. Under section 16 to 21 of Article IX of the Bangsamoro Organic Law (BOL), the law mandates the integrated system of quality education across levels, ethnicities and other sectors. The emphasis on integrated education as integral part of the BOL guarantees an easier path of IHMES in the Bangsamoro Autonomous Region. The law makes sure the congruence of the implementations of IHMES nationwide and in the BARMM. By and large, the PMEB will play as an umbrella body addressing all concerns on Madrasah education akin to the case of Philippine Halal Export Development and Promotion Board mandated by RA No. 10817 which is responsible for halal ecosystem in the Philippines.

\section{CONCLUSION}

The issue on madrasah education system in the Philippines is vital in the progress and development of Muslim Filipino society. The very polarized nature of madrasah institutions undoubtedly slowed down the socio-economic potentials of Muslim population for the past decades. This dilemma has brought various long term effects in the Muslim Filipino communities that remained until today without clear remedies at hand. The lack of well-designed education system for Muslims made the problems of Madrasah institutions cyclical. Government agencies that have the mandates to develop education for Muslims in the country appeared to have no profound sustainable solutions to prevent the perceived infiltration of radical ideologies in the educational institutions found in the Muslim communities. This perceived negligence on the part of the government led to the emergence of violent extremism. The liability on the increase of radical Muslim youths should not be solely borne by the diverse madaris as institutions for learning in the Muslim 
communities. But the inevitable role of the government and other stakeholders should also be scrutinized for the negligence of not giving importance and due recognition for madrasah institutions especially the traditional Arabic and toril though they existed for centuries. The available legislations and policies in the country are insufficient causing the ineffectively development of madrasah institutions. Thus, there is a need to pass an inclusive legislation which will provide a clear legal and regulatory framework, and propel the full integration of madrasah institution in the Philippine education system.

The study suggests that since IHMES had been in existence for decades and it has been proven effective to produce well-rounded individuals in various fields of expertise to some countries in Southeast Asia particularly Malaysia that have proximal socio-cultural relationships with the Philippines, the country should adopt the system. Muslim youths who will undergo IHMES will eventually become catalysts of reform and advocates of meaningful change in the Muslim communities. It is, therefore, worth adopting as an alternative education system for Muslim Filipinos given the challenges posed by radicalism in the country. Policy and administrative recommendations proposed by this study such as the reinstatement of the Office of Undersecretary for Muslim Affairs and the institution of the Bureau of Madrasah Education (BME) in the DepEd's Central Office, and the creation of the Philippine Madrasah Education Board (PMEB) must be a paramount education concern of the government if the state wants to see Muslim Filipinos participate in nation building and address their religio-cultural extremism. The BARMM government, as mandated by the Bangsamoro Organic Law, should push for the realization of the IHMES in the Bangsamoro areas in order to sustain the gains of the waves of Muslim revolutionary movements and realize the aspiration of the Bangsamoro people. Likewise, IHMES should also be promoted in other cities and provinces where Muslims have significant numbers so as to produce competitive human resource and address various socioeconomic and political problems in the Muslim Filipino communities particularly violent extremism. The nationwide promotions of IHMES will eventually level the field of bureaucracy and open the opportunities for Muslims Filipinos to actively participate in various socioeconomic activities. This will help Muslim communities sustainably progress and eventually uplift their status in the Philippine multicultural society.

\section{References}

Arsad, N. A. (2007). A Framework for Integration of Madrasah into the Basic Education Curriculum. Unpublished master's thesis. University of the Philippines.

Al-Attas, S. N. (1980). Concept of Education in Islam. Kuala Lumpur: International Institute of Islamic Thought and Civilization.

Ali, M. M. (2017). Issues in Islamization of Human Knowledge: Civilization Building Discourse on Contemporary Muslim Thinkers. Kuala Lumpur: International Islamic University Malaysia Press.

Abubakar, C. A. (1983). The Islamization of Southern Philippines: An Overview. In Filipino Muslims: Their Social Institutions and Cultural Achievements, edited by Felipe L. Jocano, 6-13. Quezon City: Asian Center, University of the Philippines.

Boransing, M., Magdalena, F. V., \& Lacar, A. Q. (1987). The Madrasah Institution in the Philippines: Historical and Cultural 
Perspectives, with a Directory. Tokyo: The Toyota Foundation.

Carrol, B. J. (2007). A Dialogue of Civilizations: Gulen's Islamic Ideals and Humanistic Discourse. New Jersey: The Light, Inc..

Cayamodin, J. R. (2019). Integrated and Holistic Madrasah Education System (IHMES): An Alternative Madrasah Education System for Muslim-Filipinos. UP CIDS Policy Brief Series 2019-03.

Curo, N. S. (2015). A Way Forward: A Case Study of Integrated Holistic Education System in the Philippines. Unpublished master's thesis. University of the Philippines.

Curo, N. S. (2019). The Marawi Siege: Perception of Crucial Stakeholders on Countering Violent Extremism and Terrorism. Unpublished master's thesis. University of the Philippines.

Hadji Latif, S. D. (2014). Islamic Education: Opportunities and Challenges in Secular Philippine State. SAINTEKBU: Jurnal Sains dan Teknologi, 7(1), 70-84. http://ejournal.unwaha.ac.id/index.php/sai ntek/article/view/73/73

Kimpa, S. H. (1991). Some Administrative Problems of Madaris in the Province of Sulu. University of the Philippines.

Lukens-Bull, R. (2010). Madrasa By Any Other Name: Pondok, Pesantren, and Islamic Schools in Indonesia and Larger Southeast Asian Region. Journal of Indonesian Islam, 4(1), $1-21$. https://doi.org/10.15642/JIIS.2010.4.1.121.

Madale, N. T. (1981). Educational Goals and the Search for National Identity. In N. T. Madale (Ed.), The Muslim Filipinos: A Book of Readings, 248-255. Quezon City: Alemar-Phoenix Publishing House, Inc..
Majul, C. A. (1986). The Education of the Muslims in the Philippines: History, Present Situation and Problems. In L. Q. Lacar, G. T. Puno \& N. T. Moner (Eds.), Madrasah Education in the Philippines and Its Role in National Integration, 10122. Iligan City: Coordination Center for Research and Development, MSU IIT.

Marohomsalic, N. A. (1995). Aristocrats of the Malay Race: A History of the Bangsa Moro in the Philippines. Marawi City: Mindanao State University.

Maute, Y. B. (2018). Ethnographic Perspective on the Dynamics of Violent Extremist Groups in the Philippines: The Dawla Islamiyyah (Maute Group). Unpublished master's thesis. University of the Philippines.

Muhammed, H. (2012). Integrated and Holistic Education System and its Application. Lecture, Teachers Training Lecture. Adni Islamic School, Kuala Lumpur. Delivered on January 5, 2012.

Republic of the Philippines. 2010. Republic Act No. 9997, "An Act Creating the National Commission on Muslim Filipinos Defining Its Powers, Functions and Responsibilities and Appropriating Funds Therefor and for Other Purposes (National Commission on Muslim Filipinos Act of 2009)." February $10^{\text {th }}$, 2010.

Republic of the Philippines. 2016. Republic Act No. 10817. "An Act Instituting the Philippine Halal Export Development and Promotion Program, Creating for the Purpose the Philippine Halal Export Development and Promotion Board, and for other purposes.” May 16 2016.

Republic of the Philippines. 2018. Republic Act No. 11054 (Repealing for the Purpose RA 
No. 6734 as amended by Republic Act No. 9054), "An Act Providing for the Organic Law for the Bangsamoro Autonomous Region in Muslim Mindanao.” July 23 $3^{\text {rd }}, 2018$.

Republic of the Philippines. 2016. Republic Act No. 10908. "An Act Mandating the Integration of Filipino-Muslim and Indigenous Peoples History, Culture and Identity in the Study of Philippine History in both Basic and Higher Education." July $21^{\text {st }}, 2016$.

Republic of the Philippines. 1990. Republic Act No. 6848. "An Act Providing for the 1989 Charter of the Al-Amanah Islamic Investment Bank of the Philippines, Authorizing its Conduct of Islamic Banking Business, and Repealing for this Purpose Presidential Decree No. 264 as Amended by Presidential Decree No. 542 (Creating the Philippine Amanah Bank)." January 1990.

Republic of the Philippines. 2006. Executive Oder No. 570: Institutionalizing Peace Education in Basic Education and Teacher Education, September 26, 2006.

Republic of the Philippines. House of Representatives (Seventeenth Congress). 2017. House Bill No. 6644, "An Act Creating the Bureau of Madrasah Education (BME) in the Department of Education (DepEd) to strengthen the Madrasah Education Program and Appropriating Funds Therefor (Madrasah Integration Act of 2017)." Filed November 8, 2017.

Republic of the Philippines. Department of Education. DepEd Order No. 51, s. 2004: Standard Curriculum for Elementary Public Schools and Private Madaris.
Republic of the Philippines. Department of Education. DepEd Order No. 40, s. 2011: Amendment to DepEd Order No. 51, s. 2004.

Republic of the Philippines. The Tripoli Agreement. Signed on December 23, 1976.

Republic of the Philippines. The Comprehensive Agreement on the Bangsamoro. Signed on March 27, 2014.

Republic of the Philippines. The Final Peace Agreement. Signed on September 2, 1996

Saqeb, G. N. (2000). Some Reflections on Islamization of Education Since 1977 Makkah Conference: Accomplishments, Failures and Tasks Ahead. Intellectual Discourse 8(1), 45-68. https://journals.iium.edu.my/intdiscourse/ index.php/islam/article/view/481.

Sekolah Islam Adni. n.d.a. "About Us | Sekolah Islam Adni." Sekolah Islam Adni. Accessed November. $\quad 21, \quad 2018$. http://adni.edu.my/about/.

Sekolah Islam Adni. n.d.b. "Our Philosophy | Sekolah Islam Adni." Sekolah Islam Adni. Accessed November. 21, 2018. http://adni.edu.my/our-philosophy-2/.

Tamano, M. A. (1981). How to Solve the Muslim Problem Without Bullets. In N. T. Madale (Ed.), The Muslim Filipinos: A Book of Readings, 310-322. Quezon City: Alemar-Phoenix Publishing House, Inc.. 